\title{
Inhibition of phenol on the rates of ammonia oxidation by Nitrosomonas europaea grown under batch, continuous fed, and biofilm conditions
}

\section{Authors: Ellen G. Lauchnor \& Lewis Semprini}

NOTICE: this is the author's version of a work that was accepted for publication in Water Research. Changes resulting from the publishing process, such as peer review, editing, corrections, structural formatting, and other quality control mechanisms may not be reflected in this document. Changes may have been made to this work since it was submitted for publication. A definitive version was subsequently published in Water Research, 47, 13, September 2016. DOI\#10.1016/j.watres.2013.04.052.

Lauchnor EG, Semprini L, "Inhibition of phenol on the rates of ammonia oxidation by Nitrosomonas europaea grown under batch, continuous fed, and biofilm conditions," Water Resources Sept 2013, 47(13): 4692-4700. 


\title{
Inhibition of phenol on the rates of ammonia oxidation by Nitrosomonas europaea grown under batch, continuous fed, and biofilm conditions
}

\section{Ellen G. Lauchnor ${ }^{a}{ }_{*}$, Lewis Semprini ${ }^{b}$}

\footnotetext{
${ }^{a}$ Center for Biofilm Engineering, Montana State University, 366 EPS, PO Box 173980, Bozeman, MT 59717, USA ${ }^{b}$ School of Chemical, Biological and Environmental Engineering, Oregon State University, Corvallis, OR 97331, USA
}

\author{
Keywords: \\ Biofilm \\ Ammonia oxidizing bacteria \\ Phenol \\ Oxygen microsensors \\ Specific oxygen uptake rates
}

A B S T R A C T

Ammonia oxidation by Nitrosomonas europaea, an ammonia oxidizing bacterium prevalent in wastewater treatment, is inhibited in the

presence of phenol, due to interaction of the phenol with the ammonia monooxygenase enzyme. Suspended cells of N. europaea were

cultured in batch reactors and continuous flow reactors at dilution rates of $0.01 \mathrm{e} 0.2 \mathrm{~d} 1-$. The rate of ammonia oxidation in the continuous cultures correlated to the dilution rate in the reactor. The batch and continuous cultures were exposed to $20 \mathrm{mM}$ phenol and ammonia oxidation activity was measured by specific oxygen uptake rates (SOURs). Inhi-bition of NH oxidation by $20 \mathrm{mM}$ phenol ranged from a $77 \%$ reduction of SOUR observed with suspended cells harvested during exponential growth, to $26 \%$ in biofilms. The extent of inhibition was correlated with ammonia oxidation rates in both suspended and biofilm cells, with greater percent inhibition observed with higher initial rates of $\mathrm{NH}_{3}$ oxidation. In biofilm grown cells, an increase in activity and phenol inhibition were both

observed upon dispersing the biofilm cells into fresh, liquid medium. Under higher oxygen tension, an increase in the $\mathrm{NO}_{2}^{-}$ production of the biofilms was observed and biofilms were more susceptible to phenol inhibition. Dissolved oxygen microsensor measurements showed oxygen limited conditions existed in the biofilms. The ammonia oxidation rate was much lower in biofilms, which were less inhibited during phenol exposure. The results clearly indicate in both suspended and attached cells of N. europaea that a higher extent of phenol inhibition is positively correlated with a higher rate of $\mathrm{NH}_{3}$ oxidation (enzyme turnover).

\section{Introduction}

Nitrosomonas europaea is a well-characterized ammonia oxidizing bacterium (AOB) that oxidizes ammonia to nitrite and is prevalent in wastewater treatment processes that employ biological nitrogen removal (Prosser, 1989). The pres-ence of aromatic hydrocarbons such as phenol in industrial wastewater inhibits $\mathrm{NH}_{3}$ oxidation by N. europaea and can result in failure of nitrogen removal (Amor et al., 2005). The use of biofilms, microbial communities attached to surfaces, for wastewater treatment provides protection for sensitive bacteria such as N. europaea, which are embedded within the biofilm. N. europaea, like all AOB, utilizes ammonia monooxygenase (AMO) to oxidize ammonia (NH3) to nitrite (NO2 ) as the sole energy generating reaction for growth and metabolism (Wood, 
1986). The oxidation of $\mathrm{NH}_{3}$ to $\mathrm{NO}_{2}^{-}$is a two-step process. The first step of $\mathrm{NH}_{3}$ oxidation to hydroxylamine $\left(\mathrm{NH}_{2} \mathrm{OH}\right)$ is catalyzed by AMO, while the second oxidation step to $\mathrm{NO}_{2}^{-}$is catalyzed by hydroxylamine oxidoreductase (HAO) (Arp et al., 2002). AMO is a non-specific enzyme with a wide substrate range capable of co-metabolic oxidation of aliphatic (Rasche et al., 1990) and aromatic hydrocarbons (Keener and Arp, 1993, 1994). Phenol, the compound of interest in this study is oxidized to hydroquinone (Hyman et al., 1985; Keener and Arp, 1994).

Phenol was chosen for this investigation as a model aromatic compound that is co-metabolized by N. europaea and is often present in industrial wastewaters that may also contain high ammonia concentrations and undergo biological treatment. Additionally, exposure to phenol has been studied in both biofilms and suspended cells of $N$. europaea, resulting in the observation that ammonia oxidation in the biofilms was less inhibited than suspended cells (Lauchnor et al., 2011). The oxidation by AMO of co-metabolic substrates inhibits $\mathrm{NH}_{3}$ oxidation by competing for the enzyme active site or inhibiting electron flow and causing cellular energy drain (Ely et al., 1997).

The biofilm phenotype has been implicated in resistance to many bacterial inhibitors, including antibiotics (Anderson and O'Toole, 2008; Costerton et al., 1999). A large body of biofilm research has focused on determining mechanisms of biofilm resistance, which some previous studies suggest may be due simply to stationary phase growth. Stationary phase or slow growth of bacteria has been linked to resistance to antimicrobial agents in other bacterial species and is thought to be a factor in biofilm resistance (Mah and O'Toole, 2001; Spoering and Lewis, 2001). Additionally, antimicrobial agents have been shown to be less effective on eradication of slow growing or stationary cells (Borriello et al., 2004). In biofilms, cells often have slower metabolism due to nutrient or $\mathrm{O}_{2}$ limitations, which has also been observed in N. europaea biofilms (Lauchnor et al., 2011).

$N$. europaea has been examined under different growth states to study inhibition of $\mathrm{NH}_{3}$ oxidation (Chandran and Love, 2008; Radniecki et al., 2009). A study of N. europaea biofilms reported that established biofilms were less inhibited by the nitrification inhibitor nitrapyrin and exhibited reduced growth rates compared to suspended cells (Powell and Prosser, 1992). Additionally, exponential cells of N. europaea exhibited greater inhibition of $\mathrm{NH}_{3}$ oxidation when exposed to nitrapyrin compared to stationary-phase cultures (Powell and Prosser, 1986). A study of cadmium inhibition of N. europaea, based on $\mathrm{O}_{2}$ uptake rates, demonstrated that cells in stationary phase were less inhibited over time than during exponential growth (Chandran and Love, 2008). In our previous work, pure culture biofilms of N. europaea were less inhibited than suspended cells during phenol exposure, with about $60 \mu \mathrm{M}$ causing a $50 \%$ reduction of $\mathrm{NH}_{3}$ oxidation in biofilms compared to $99 \%$ inhibition in suspended cells (Lauchnor et al., 2011). These observations with $N$. europaea led us to investigate the effect of growth state and $\mathrm{NH}_{3}$ oxidation rates of the cells on $\mathrm{NH}_{3}$ inhibition by phenol. This study aimed to determine whether reduced $\mathrm{NH}_{3}$ oxidation activity or strictly biofilm phenotype was responsible for previously observed resistance of $N$. europaea biofilms to the nitritation inhibitor, phenol.
Microsensor profiles have been used to study rates of substrate consumption in nitrifying biofilms (Gieseke and deBeer, 2004) as well as changes in $\mathrm{NH}_{3}$ and $\mathrm{O}_{2}$ uptake during exposure to inhibitory compounds (Li and Bishop, 2002; Satoh et al., 2005). A study by Satoh et al. showed that 2-chlorophenol inhibited nitrification and $\mathrm{O}_{2}$ uptake in a biofilm, although the deeper layers were still active due to limited penetration of the inhibitor (Satoh et al., 2005). In our work, microelectrodes were used to evaluate inhibition of biofilms via changes in oxygen uptake rates, which were compared to similar rate data from suspended cultures.

This study compared phenol inhibition of $N$. europaea grown under different conditions including batch culture, chemostats, fill-and-draw reactors and biofilms, to determine if inhibition was a function of the rate of ammonia oxidation instead of biofilm phenotype. The activities of the cells from the different reactors were evaluated by measuring $\mathrm{O}_{2}$ uptake rates with and without exposure to phenol. This investigation contributes to the understanding of nitrifying biofilms by determining why biofilms of $N$. europaea appear to be less inhibited than batch grown cells by the AMO inhibitor, phenol.

\section{Materials and methods}

\subsection{N. europaea cell growth in batch reactors}

Batch cultures of N. europaea (ATCC, 19718) were grown for batch inhibition tests by inoculating frozen stocks into $4 \mathrm{~L}$ flasks containing 2L medium and shaking for 3 days at 150 RPM and $30{ }^{\circ} \mathrm{C}$. The batch grown cells were also used to inoculate biofilm and suspended growth reactors. AOB medium consisted of: $25 \mathrm{mM}\left(\mathrm{NH}_{4}\right)_{2} \mathrm{SO}_{4}, 3.77 \mathrm{mM} \mathrm{Na}_{2} \mathrm{CO}_{3}$, $40 \mathrm{mM} \mathrm{KH}_{2} \mathrm{PO}_{4}, 730 \mu \mathrm{M} \mathrm{MgSO}_{4}, 200 \mu \mathrm{M} \mathrm{CaCl}_{2}, 9.9 \mu \mathrm{M} \mathrm{FeSO}_{4}$, $16.5 \mu \mathrm{M}$ EDTA free acid, and $0.65 \mu \mathrm{M} \mathrm{CuSO}_{4}$.

The rate of ammonia oxidation by batch cultivated cells was measured by a short-term 30 min rate experiment where $\mathrm{NO}_{2}^{-}$concentration was measured every five minutes and the rate of accumulation was calculated. Cells were harvested during exponential growth in batch reactors for phenol inhibition experiments.

\subsection{Cell growth in fill-and-draw reactors}

Suspended cells of N. europaea were cultured in fill-and-draw reactors where volumes of the liquid cultures were replaced by fresh medium daily to mimic continuous flow conditions and create long cell residence times. In the fill-and-draw reactors, HEPES medium was used, consisting of AOB medium (50 $\mathrm{mM} \mathrm{NH}_{3}$ ) with $20 \mathrm{mM}$ HEPES buffer ( $\mathrm{pH} 7.8$ ) and $10 \mu \mathrm{M}$ $\mathrm{KH}_{2} \mathrm{PO}_{4}$ in lieu of $40 \mathrm{mM} \mathrm{KH}_{2} \mathrm{PO}_{4}$ buffer. Reactors consisted of $500 \mathrm{~mL}$ Erlenmeyer flasks with $200 \mathrm{~mL}$ of HEPES medium inoculated with $\mathrm{N}$. europaea and placed on a rotating shaker table at $150 \mathrm{RPM}$ and $30{ }^{\circ} \mathrm{C}$. The reactors were sealed with foam plugs and covered with foil to allow air exchange and maintain sterility. Cells and medium from each flask were removed daily and aseptically replaced with fresh HEPES medium at volumes to achieve desired dilution rates. The $\mathrm{pH}$ was adjusted daily to 7.8. Triplicate reactors were maintained at each of four different dilution rates of $0.01,0.02,0.05$, and 
$0.2 \mathrm{~d}^{-1}$, which corresponded to hydraulic and cell residence times of 100, 50, 20 and 5 d, respectively. Biomass protein concentration, $\mathrm{NO}_{2}^{-}$accumulation and $\mathrm{pH}$ were monitored in the flasks. For phenol exposure experiments and oxygen uptake measurements, cells in liquid media were aseptically removed from the flasks and placed into sterile $150 \mathrm{~mL}$ bottles.

The fill-and-draw reactors were maintained for 45 days while monitoring $\mathrm{NO}_{2}^{-}$production and cell growth. The concentrations of $\mathrm{NO}_{2}^{-}$and protein achieved pseudo-steady-state in triplicate reactors for all dilution rates. The activity of the cells was calculated by dividing $\mathrm{NO}_{2}^{-}$concentration by the biomass protein concentration and dilution rate of the reactor.

\subsection{Cell growth in chemostat reactors}

Chemostats were maintained at dilution rates of 0.14 and $0.03 \mathrm{~d}^{-1}$ to evaluate phenol inhibition and to compare with the results of fill-and-draw reactors. N. europaea was cultivated at $30{ }^{\circ} \mathrm{C}$ in continuous fed Bioflow 110 bioreactors (New Brunswick Scientific, Edison, NJ) with HEPES medium. For phenol inhibition experiments and specific oxygen uptake rate (SOUR) measurements, cells were harvested as completely mixed liquid samples that were transferred aseptically from a port in the vessel directly into sample vials. $\mathrm{NO}_{2}^{-}$production was measured and normalized to biomass concentration by dividing the $\mathrm{NO}_{2}^{-}$concentration in the chemostat by the dilution rate and normalizing to protein concentration.

\subsection{SOUR inhibition tests}

Suspended cells exposed to 0 (control) or $20 \mu \mathrm{M}$ phenol were subsequently evaluated using SOUR tests. SOURs were performed to evaluate the rate of oxygen consumption by N. europaea before and during phenol exposure. The SOUR assay provides immediate rate measurements of $\mathrm{O}_{2}$ consumption that can be converted to $\mathrm{NH}_{3}$ oxidation or $\mathrm{NO}_{2}^{-}$ production rates based on the following stoichiometry: $\mathrm{NH}_{3}+1.5 \mathrm{O}_{2} \rightarrow \mathrm{NO}_{2}^{-}$(Radniecki et al., 2008). Samples (50 mL) from the batch, chemostat, and fill-and-draw reactors were placed in $125 \mathrm{~mL}$ Erlenmeyer flasks, adjusted to 7.8 and supplemented with $2.5 \mathrm{mM}\left(\mathrm{NH}_{4}\right)_{2} \mathrm{SO}_{4}$. Samples were then incubated with either $0 \mu \mathrm{M}$ or $20 \mu \mathrm{M}$ phenol while shaking at $150 \mathrm{RPM}$ and $30^{\circ} \mathrm{C}$ for $60 \mathrm{~min}$ prior to obtaining samples for SOUR measurements.

SOUR measurements were taken with a Clark-type oxygen electrode (Yellow Springs Instrument, Inc.) in a waterjacketed cell at $30{ }^{\circ} \mathrm{C}$ (Gilson Medical Instruments, Inc.). $\mathrm{O}_{2}$ concentration in the cell was measured over time to determine rates of uptake, which were compared for the control and phenol-treated samples. The cell contained $1.8 \mathrm{~mL}$ liquid sample and a stir bar for mixing. For the AMO-SOUR measurement, $2.5 \mathrm{mM}\left(\mathrm{NH}_{4}\right)_{2} \mathrm{SO}_{4}$ was added to provide an excess of substrate. To halt AMO activity $100 \mu \mathrm{M}$ allylthiourea was added and the AMO-independent $\mathrm{O}_{2}$ uptake, or HAO-SOUR, was measured by adding $750 \mu \mathrm{M} \mathrm{NH} \mathrm{NH}_{2} \mathrm{OH}$ as alternative substrate for the HAO enzyme. This measurement helps to determine if $\mathrm{O}_{2}$ uptake is reduced due to inhibition that is independent of AMO activity. The percent inhibition was determined by dividing the AMO-SOUR of phenol exposed cells by that of the control cells for each reactor.

\subsection{Biofilm growth and inhibition tests}

For a comparison between attached and suspended growth states, biofilms were exposed to phenol and $\mathrm{NO}_{2}^{-}$production was monitored to determine extent of inhibition. Biofilms of N. europaea were cultivated in a Drip Flow Biofilm Reactor (DFR) fed with HEPES medium for 4-6 weeks and inhibition experiments were performed on mature biofilms according to methods developed previously (Lauchnor et al., 2011). In brief, during phenol exposure experiments, phenol was added via a syringe pump to the influent media of two DFR channels for a period of $3 \mathrm{~h}$, with the other two DFR channels serving as controls. Effluent samples were taken from the DFR during phenol exposure to monitor $\mathrm{NO}_{2}^{-}$production and concentrations of phenol and its oxidation products. The rates of $\mathrm{NO}_{2}^{-}$production were calculated by multiplying the effluent $\mathrm{NO}_{2}^{-}$concentrations by the liquid flow rates in the DFR channels.

Most phenol exposure studies were performed under atmospheric oxygen conditions. In several of the tests however, the oxygen concentration in the DFR headspace was elevated to reduce $\mathrm{O}_{2}$ limitation in $\mathrm{N}$. europaea biofilms. Biofilms were grown to maturity under atmospheric oxygen conditions. One hour prior to the phenol addition, $\mathrm{O}_{2}$ gas was added at $1 \mathrm{~L} \mathrm{~min}^{-1}$ to the headspace of the DFR channels through $0.45 \mu \mathrm{m}$ syringe filters. Phenol inhibition tests were then performed under the elevated $\mathrm{O}_{2}$ conditions to evaluate the effect of higher $\mathrm{O}_{2}$ and increased rates. To maintain high $\mathrm{O}_{2}$ conditions, the headspace was fed with $\mathrm{O}_{2}$ gas for 2 min every $30 \mathrm{~min}$ until the end of the inhibition experiment.

\subsection{Microsensor profiles}

Dissolved oxygen (DO) microsensor measurements were performed to determine the rate of DO uptake in the biofilms. Clark-type oxygen microsensors (Unisense, Denmark) were used for measuring depth profiles of DO concentration in the biofilms. The biofilm samples were cultivated in the DFR identically to those used in the inhibition tests described above. The biofilms on glass slides were then removed from the DFR and placed into a flow cell connected to a recirculating water bath with $5 \mathrm{~L}$ of liquid medium containing $2.5 \mathrm{mM}$ $\left(\mathrm{NH}_{4}\right)_{2} \mathrm{SO}_{4}$ and $10 \mathrm{mM}$ HEPES buffer (pH 7.8) kept at a $25^{\circ} \mathrm{C}$. Microsensor measurements were made using a micromanipulator as described previously (Lauchnor et al., 2011). Control profiles of DO in the presence of $\mathrm{NH}_{4}$ were initially performed in triplicate. Phenol was then added to the medium with two sequential additions to achieve $40 \mu \mathrm{M}$ and $80 \mu \mathrm{M}$ phenol. After each addition of phenol, the recirculating system was allowed to equilibrate for $2 \mathrm{~h}$ prior to microsensor measurements. Triplicate DO profiles were taken to verify that profiles were not changing over time and the steady-state oxygen uptake was determined. The bulk fluid phase in the measuring chamber had a constant atmospheric concentration of DO $\left(257 \mu \mathrm{M}\right.$ at $25^{\circ} \mathrm{C}$ ), which differed from the DFR where the thin film flow allowed for more $\mathrm{O}_{2}$ transfer from the headspace.

The areal $\mathrm{O}_{2}$ fluxes in the biofilms were calculated from the microsensor profile data according to the diffusion-reaction equation at steady-state, which was approximated by the following difference equation (Gieseke and deBeer, 2004): 


$$
J=D_{\text {eff }} \frac{c_{a}-c_{b}}{\Delta x}
$$

where $J$ is flux in $\mu \mathrm{mol} \mathrm{cm} \mathrm{cm}^{-2} \mathrm{~s}^{-1}, D_{\text {eff }}$ is the diffusion coefficient, $c_{a}$ and $c_{b}$ are measured DO concentrations, and $\Delta x$ is the depth interval between $c_{a}$ and $c_{b}$. The reduction in $\mathrm{O}_{2}$ flux upon exposure of the biofilms to phenol was calculated by dividing the $\mathrm{O}_{2}$ flux into the phenol exposed biofilms by the flux into the same biofilm prior to phenol exposure. Since the calculation of inhibition is reduced to the ratio of concentration gradients of phenol exposed and non-exposed biofilms at the biofilm surface, determination of $D_{\text {eff }}$ is not required.

\subsection{Analytical methods}

$\mathrm{NO}_{2}^{-}$accumulation in liquid media was used to determine rates of $\mathrm{NH}_{3}$ oxidation. $\mathrm{NO}_{2}^{-}$was measured using a colorimetric assay (Hageman and Hucklesby, 1971), which was quantified by spectrophotometric analysis at a wavelength of $540 \mathrm{~nm}$. Phenol concentrations were measured by high performance liquid chromatography (HPLC), according to methods reported elsewhere (Radniecki et al., 2008). Biomass protein concentrations were determined using a microbiuret assay after a $30 \mathrm{~min}$ cell digestion in $3 \mathrm{M} \mathrm{NaOH}$ at $65^{\circ} \mathrm{C}$. Optical density at $600 \mathrm{~nm}$ was used with suspended cultures as a surrogate measurement for the biuret assay, and a standard curve was used for conversion to biomass protein concentration.

\section{Results}

\subsection{Suspended cell cultivation}

\subsubsection{Fill-and-draw reactors}

The fill-and draw reactors reached a pseudo-steady-state of protein normalized $\mathrm{NO}_{2}^{-}$production after 25 days of operation. At this time, the $\mathrm{NO}_{2}^{-}$production rates showed an increasing trend with increasing dilution rates of the reactors (Table 1). The steady-state $\mathrm{NO}_{2}^{-}$concentrations were $40-45 \mathrm{mM}$ for all reactors, and protein concentrations ranged from 2.5 to $4.5 \mathrm{mg} \mathrm{L}^{-1}$. Control SOUR measurements with cells harvested from the fill-and-draw reactors were compared to $\mathrm{NO}_{2}^{-}$production rates taken during growth of the cells in the reactors and a positive correlation was observed between the rates (Fig. 1). To provide a comparison to exponentially growing cells, SOURs and $\mathrm{NO}_{2}^{-}$production rates for cells harvested from the batch reactors are included in Table 1.

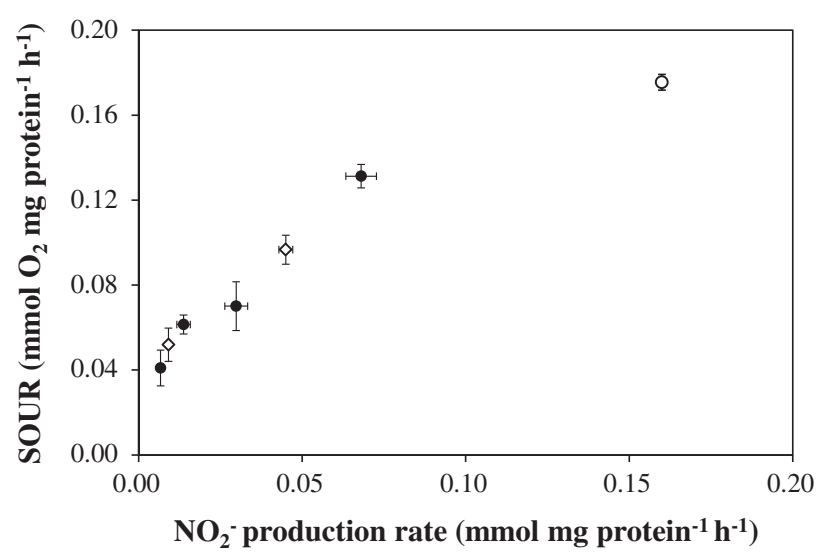

Fig. 1 - Comparison of nitrite production rates and SOURs of suspended cell reactors. Rates of batch reactors (०), chemostats $(\diamond)$ and fill-and-draw reactors $(\bullet)$. Error bars represent standard deviation of triplicate reactors for batch and fill-and-draw, and triplicate samples taken from chemostats.

\subsubsection{Chemostats}

Control SOURs of cells harvested from the chemostats with no phenol exposure fell along the same trend with the $\mathrm{NO}_{2}^{-}$ production rates observed with cells from the fill-and-draw reactors (Fig. 1). There was a positive correlation between $\mathrm{NO}_{2}^{-}$production and SOURs, although the SOURs were higher than $\mathrm{NO}_{2}^{-}$production rates and deviated more at lower dilution rates (Fig. 1). The cells at the slowest dilution rates were the most substrate limited and their activity increased in response to the addition of $\mathrm{NH}_{3}$ during the SOUR tests. The SOUR measurements were performed with added substrate at the onset of the test, which allowed for measurement of the maximum rate of $\mathrm{NH}_{3}$ turnover for the cells. The SOUR assay was representative of the AMO activity in the harvested cells, and the SOURs were therefore used for inhibition comparisons. SOURs were also found to be the most sensitive measurement to growth phase and inhibition response by others studying $N$. europaea exposure to cadmium (Chandran and Love, 2008).

During continuous culture of N. europaea, it is possible that the active fraction of cells in the chemostats and pseudochemostats was lower than the total biomass concentration

Table 1 - Activity and culture conditions of continuous and batch reactors prior to phenol exposure.

\begin{tabular}{|c|c|c|c|c|}
\hline \multirow[t]{2}{*}{ Growth reactor } & Dilution rate & \multirow[t]{2}{*}{$\mathrm{OD}_{600}$} & $\mathrm{NO}_{2}^{-}$production & Control SOURs \\
\hline & $d^{-1}$ & & $\mathrm{mmol} \mathrm{NO}_{2}^{-} \mathrm{mg}$ protein ${ }^{-1} \mathrm{~h}^{-1}$ & $\mathrm{mmol} \mathrm{O}_{2} \mathrm{mg}$ protein ${ }^{-1} \mathrm{~h}^{-1}$ \\
\hline Batch & & 0.070 & 0.16 & 0.176 \\
\hline \multirow[t]{4}{*}{ Fill-and-draw reactors } & 0.01 & 0.030 & 0.007 & 0.041 \\
\hline & 0.02 & 0.031 & 0.014 & 0.061 \\
\hline & 0.05 & 0.038 & 0.030 & 0.070 \\
\hline & 0.2 & 0.053 & 0.068 & 0.131 \\
\hline \multirow[t]{2}{*}{ Chemostats } & 0.03 & 0.073 & 0.009 & 0.052 \\
\hline & 0.14 & 0.072 & 0.045 & 0.097 \\
\hline
\end{tabular}


measured in the reactors. Here, the total protein was measured by correlating $\mathrm{OD}_{600}$ measurements to a standard curve with the microbiuret protein assay and the fraction of protein comprising active cells was not determined. Therefore, lower measurements of SOURs and $\mathrm{NO}_{2}^{-}$production rates in the continuous reactors could indicate reduced activity in all of the biomass measured, or a reduced fraction of active biomass.

\subsection{Suspended cell exposure to phenol}

AMO-SOUR measurements with cells harvested after 45 days of fill-and-draw reactor operation showed that oxygen consumption rates of control cells (no phenol) were positively correlated with the dilution rates in the reactors (Fig. 2A). The rates for the chemostat-grown cells and fill-and-draw cells fell along the same linear trend between dilution rate and SOUR measurement, indicating that the fill-and-draw reactors were sufficiently accurate approximations of continuously fed reactors.

When suspended cells were exposed to $20 \mu \mathrm{M}$ phenol, AMO-SOURs decreased to the same level for all the
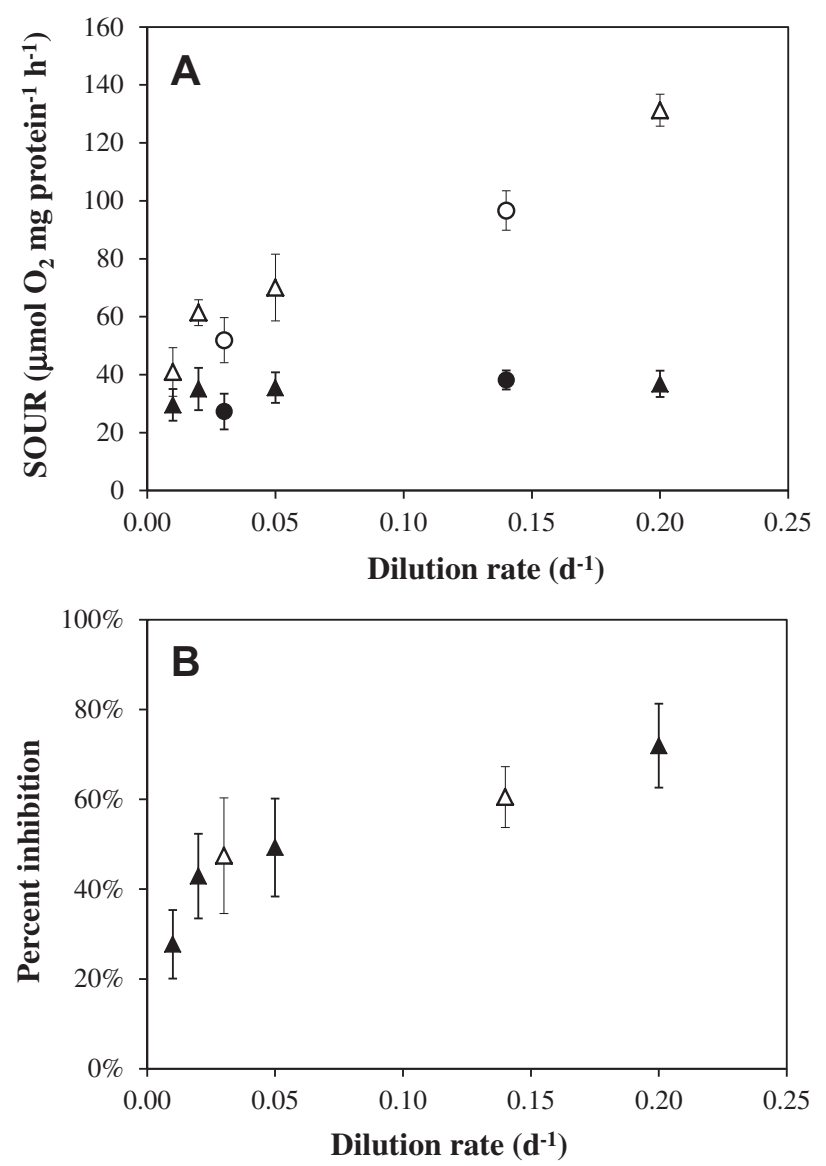

Fig. 2 - Oxygen uptake rates and percent inhibition of chemostat and fill-and-draw cells. A) Cells from fill-anddraw reactors (triangles) and chemostats (circles) exposed to $0 \mu \mathrm{M}$ phenol (open symbols) and $20 \mu \mathrm{M}$ phenol (closed symbols). B) Inhibition of fill-and-draw cells $(\Delta)$ and chemostat cells $(\triangle)$ determined by ratio of phenol and control SOURs. Percent inhibition $=\left(1-\left(\right.\right.$ SOUR $\left.R_{\text {phenol }}\right) /$ $\left.\left(\mathrm{SOUR}_{\text {control }}\right)\right)^{*} 100 \%$. Error bars represent standard deviations of biological triplicates. chemostats and fill-and-draw reactors, within the standard deviations of the measurements (Fig. 2A). Therefore, upon exposure to the same phenol concentration of $20 \mu \mathrm{M}$, cells grown at higher dilution rates experienced greater reduction in SOUR activity. HAO-SOURs did not change between the control and phenol treated samples (data not shown); only the AMO-SOURs were inhibited, which supports previous evidence that phenol inhibition is specific to the AMO enzyme (Radniecki et al., 2008).

The results of the AMO-SOUR measurements indicate that the extent of inhibition due to phenol exposure was positively correlated to dilution rates, and therefore bacterial growth rates, in the chemostat and fill-and-draw reactors (Fig. 2B).

The percent inhibition of SOURs upon $20 \mu \mathrm{M}$ phenol exposure in batch, chemostat and fill-and-draw grown cells were compared to protein normalized $\mathrm{NO}_{2}^{-}$production rates (Fig. 3). $\mathrm{NO}_{2}^{-}$production rates were used as the measure of $\mathrm{NH}_{3}$ oxidation activity instead of SOURs in order to compare results to biofilm experiments. Regardless of the type of suspended cell growth reactor (batch, fill-and-draw or chemostat), the degree of inhibition of suspended cells positively correlated with increasing rates of $\mathrm{NO}_{2}^{-}$production.

\subsection{Biofilm exposure to phenol and comparison to suspended cells}

When the biofilms were exposed to $18 \pm 1 \mu \mathrm{M}$ phenol in the DFR for $2 \mathrm{~h}, 26 \%$ inhibition was observed (Fig. 3). The change in $\mathrm{NO}_{2}^{-}$production was used to determine percent inhibition because it was not feasible to measure the inhibition via SOURs in the DFR biofilms. The biofilm results are similar to results presented in our previous study on N. europaea biofilm exposure to phenol and toluene (Lauchnor et al., 2011). The previous study showed that biofilm cells were more tolerant to phenol than batch cells, as is shown in Fig. 3 where batch cells exhibited $77 \%$ inhibition compared to $26 \%$ inhibition in

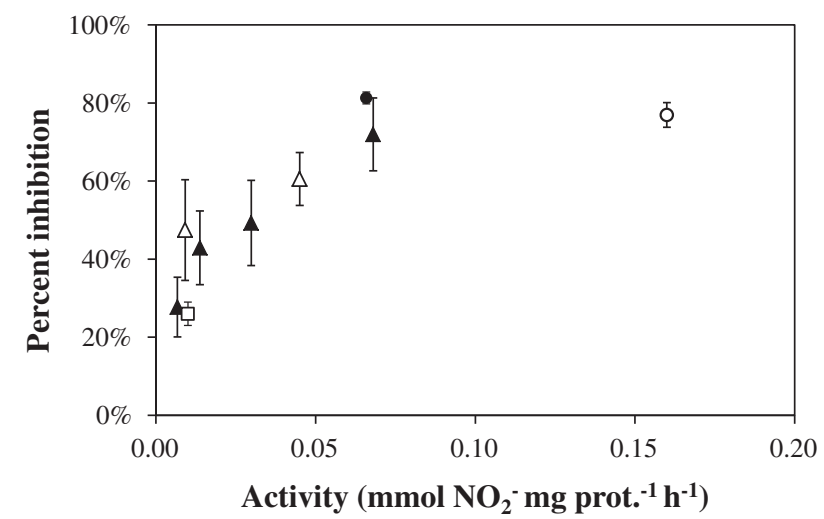

Fig. 3 - Percent inhibition of $\mathrm{NH}_{3}$ oxidation during exposure to $20 \mu \mathrm{M}$ phenol under different culture conditions of $\mathbf{N}$. europaea. Inhibition of batch cells (०), filland-draw cells $(\Delta)$, chemostat cells $(\Delta)$, biofilm-grown cells suspended into liquid $(\bullet)$ and biofilms $(\square)$. Error bars represent standard deviation of triplicates for suspended cell data and range of duplicate for biofilms. Data for biofilm cells suspended in liquid were taken from (Lauchnor et al., 2011). 


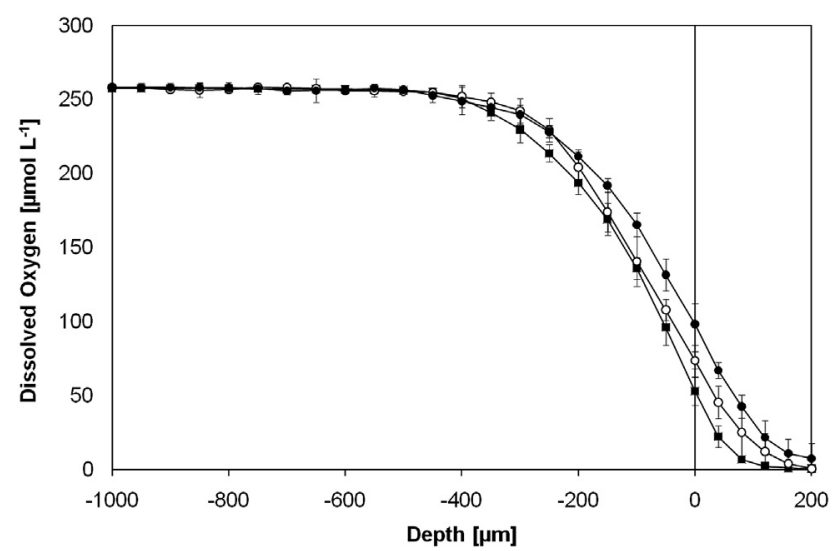

Fig. 4 - DO microsensor profiles of biofilms exposed to $0 \mu \mathrm{M}(\square), 40 \mu \mathrm{M}(\circ)$, and $80 \mu \mathrm{M}$ phenol (०). The biofilm surface was located at a depth of $0 \mu \mathrm{m}$. Error bars represent standard deviations of triplicate profiles.

biofilms. However, cells from the fill-and-draw reactors at the slowest dilution rate that had a similar $\mathrm{NO}_{2}^{-}$production rate as the biofilm were only $28 \%$ inhibited, which was not statistically different than the biofilms. The results of these inhibition comparisons at $20 \mu \mathrm{M}$ phenol demonstrate that with decreasing $\mathrm{NH}_{3}$ oxidation activity in continuous cultures, suspended cells of $N$. europaea may potentially become as tolerant to phenol as biofilm cells.

The phenol inhibition in the suspended cells was compared with our previous results (Lauchnor et al., 2011) of phenol inhibition in biofilm cells that were scraped from the biofilm support, suspended in fresh liquid medium and exposed to phenol (Fig. 3). The activity of the biofilm cells increased to $50 \%$ of the batch rates upon dispersing them into fresh medium. The inhibition was equal to that of the batch cells and significantly increased from the percent inhibition observed in the intact biofilms. This comparison indicates that the lower nitrification activity in the biofilms due to substrate limitations was likely responsible for the lower inhibition that was observed.

\subsection{Microsensor profiles of biofilms}

DO profiles measured in biofilms in the presence of $5 \mathrm{mmol} \mathrm{L}{ }^{-1} \mathrm{NH}_{4}-\mathrm{N}$ at $\mathrm{pH} 7.8$ are shown in Fig. 4. With no phenol added, the uninhibited profiles showed that DO is consumed in the biofilms and reaches negligible concentrations before reaching a depth of $200 \mu \mathrm{m}$. The fact that oxygen was depleted to essentially zero inside the biofilms with no phenol exposure also indicates that $\mathrm{O}_{2}$ was the limiting substrate for the cells.

Upon addition of both 40 and $80 \mu \mathrm{M}$ phenol, the $\mathrm{O}_{2}$ concentration increased in the biofilm as $\mathrm{NH}_{3}$ oxidation was reduced due to inhibition (Fig. 4). The $\mathrm{O}_{2}$ profiles taken during phenol exposure demonstrate an increase in $\mathrm{O}_{2}$ concentration inside the biofilm due to inhibition of $\mathrm{NH}_{3}$ oxidation. The percent reduction of $\mathrm{O}_{2}$ flux into the biofilm was only $17 \%$ and $19 \%$ for $40 \mu \mathrm{M}$ and $80 \mu \mathrm{M}$ phenol exposure, respectively. In the DFR, exposure to similar phenol concentrations of $36 \mu \mathrm{M}$ and $69 \mu \mathrm{M}$ phenol resulted in $37 \%$ and $63 \%$ inhibition, respectively, based on decreases in $\mathrm{NO}_{2}^{-}$production (Table 2).

\subsection{Phenol inhibition of biofilms us. oxygen}

Based on the microsensor measurements, which demonstrated that $\mathrm{O}_{2}$ was limiting in $\mathrm{N}$. europaea biofilms, additional $\mathrm{O}_{2}$ was supplied in the DFR headspace to increase $\mathrm{NH}_{3}$ oxidation rates. This permitted evaluation of phenol inhibition at two different rates of $\mathrm{NH}_{3}$ oxidation in the biofilms. For these tests, the biofilms of N. europaea in the DFR were exposed to $50 \mu \mathrm{M}$ phenol first under atmospheric conditions and subsequently under pure oxygen headspace to achieve a higher nitrification rate comparison. The atmospheric inhibition test was performed on the biofilms and then a recovery period of two days was allowed before the second $50 \mu \mathrm{M}$ phenol inhibition test was performed. The control $\mathrm{NO}_{2}^{-}$production rates during the initial atmospheric test were on average $0.023 \mathrm{mmol} \mathrm{NO}_{2}^{-} \mathrm{h}^{-1}$ per biofilm channel (Fig. 5). After the initial test (1-4 h), $\mathrm{NO}_{2}^{-}$production rates of phenol exposed biofilms recovered to $97 \%$ of the control rates between 5 and $50 \mathrm{~h}$, demonstrating essentially complete recovery of the treated biofilms between exposures. After the addition of pure $\mathrm{O}_{2}$ gas into the DFR headspace at $52.5 \mathrm{~h}$, the rates of $\mathrm{NO}_{2}^{-}$ production showed a $56 \%$ increase from atmospheric headspace conditions to an average of $0.038 \mathrm{mmol} \mathrm{NO}_{2}^{-} \mathrm{h}^{-1}$ per channel.

Under the atmospheric headspace conditions, $\mathrm{NO}_{2}^{-}$production in the biofilms decreased to $0.009 \mathrm{mmol} \mathrm{NO}_{2}^{-} \mathrm{h}^{-1}$ upon $50 \mu \mathrm{M}$ phenol exposure, or by $61 \%$ (Fig. 5). In the high $\mathrm{O}_{2}$ test, $\mathrm{NO}_{2}^{-}$production was inhibited $85 \%$ compared to rates prior to the inhibition test. The phenol inhibition of $85 \%$ in the biofilms under elevated $\mathrm{O}_{2}$ concentration was greater than the

\section{Table 2 - Comparison of inhibition between biofilms and batch cells exposed to high phenol concentrations.}

$$
\mathrm{NO}_{2}^{-} \text {production mmol mg protein }{ }^{-1} \mathrm{~h}^{-1} \quad \text { Phenol } \mu \mathrm{M}
$$

Inhibition \%

\begin{tabular}{|c|c|c|c|}
\hline Batch reactor & 0.116 & 40 & $98 \%$ \\
\hline Biofilm - suspended into liquid (Lauchnor et al., 2011) & 0.066 & 82 & $97 \%$ \\
\hline \multirow[t]{2}{*}{ Biofilm - DFR } & 0.018 & 36 & $37 \%$ \\
\hline & 0.011 & 69 & $63 \%$ \\
\hline \multirow[t]{2}{*}{ Biofilm - microsensor chamber model } & $0.0015^{\mathrm{a}}$ & 40 & $17 \%$ \\
\hline & & 80 & $19 \%$ \\
\hline
\end{tabular}

a Estimated from model simulation (Lauchnor, 2011). 


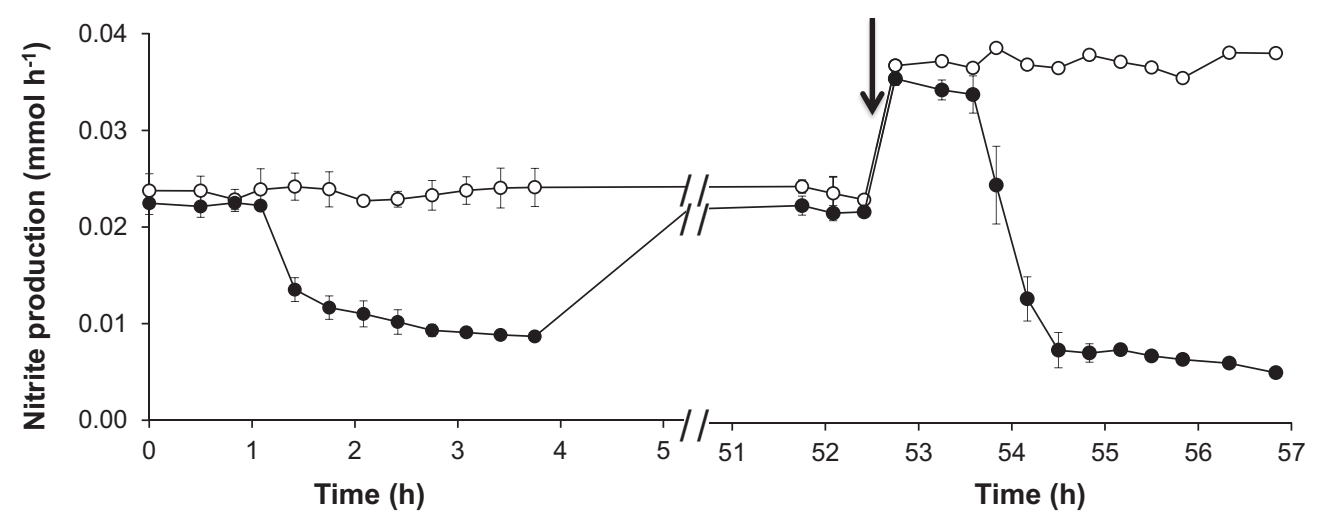

Fig. 5 - Nitrite production by N. europaea biofilms in DFR during phenol exposure under different $\mathrm{O}_{2}$ conditions. Phenol exposure under atmospheric $\mathrm{O}_{2}(1 \mathrm{~h}-4 \mathrm{~h})$ and pure $\mathrm{O}_{2}$ headspace $\left.(53 \mathrm{~h}-57 \mathrm{~h})\right)$, during addition of $0 \mu \mathrm{M}$ phenol ( $)$ and $50 \mu \mathrm{M}$ phenol (०). Arrow denotes beginning of $\mathrm{O}_{2}$ gas addition to headspace. Error bars represent range of duplicate biofilms.

inhibition observed under atmospheric conditions. This result is consistent with the relationship in suspended cells where increased $\mathrm{NO}_{2}^{-}$production rates correlated with increased percent inhibition. The experimental conditions of using the same biofilms for subsequent testing under elevated $\mathrm{O}_{2}$ conditions allowed for direct comparison of results without variation in biofilm age, thickness or activity. The fast response of the cells to higher oxygen concentration in the headspace suggests that under these conditions, $\mathrm{O}_{2}$ limitations control the $\mathrm{NH}_{3}$ oxidation kinetics of the biofilms. The results showed increased inhibition with increased activity that was consistent with the observations of biofilm grown cells dispersed in media, which were more inhibited by phenol than when present in an intact biofilm (Fig. 3). The biofilm inhibition results with elevated $\mathrm{O}_{2}$ confirmed that with attached cells as well as suspended cells, increasing the $\mathrm{NH}_{3}$ oxidation rates resulted in increased inhibition.

\section{Discussion}

\subsection{Growth rate dependence of phenol inhibition in suspended cells}

In this study, phenol inhibition increased with increasing dilution rate in suspended cultures of N. europaea (Figs. 2B and 3). In these liquid cultures, the supply of $\mathrm{NH}_{3}$ and other nutrients is limited by the dilution rate; therefore the cells that experience a slower addition of fresh nutrients behave similar to a stationary state of growth. These results indicate that harvesting cells at different stages of growth would affect the degree of inhibition observed.

Co-metabolic oxidation of alternative substrates by AMO may compete with $\mathrm{NH}_{3}$ oxidation and potentially consume available reductant in the cell. Previous studies of N. europaea have shown that phenol is co-metabolically oxidized to hydroquinone by AMO (Hyman et al., 1985). However, the rate of phenol oxidation was at least two orders of magnitude lower than $\mathrm{NH}_{3}$ oxidation. The oxidation of phenol therefore would not be expected to significantly deplete the reductant supply in the cell as the electrons consumed by phenol will be a small fraction of those generated. However, the inhibition of a co-metabolic substrate such as phenol may disrupt the flow of reductant in the cell by inhibiting AMO oxidation of $\mathrm{NH}_{3}$ and therefore cause energy drain (Ely et al., 1997). These inhibitory actions may have more effect on cells that are more rapidly oxidizing $\mathrm{NH}_{3}$ and have greater AMO turnover and flow of reductant, such as during exponential phase growth.

\subsection{Influence of activity on phenol inhibition in biofilms}

In this study, the reduction in $\mathrm{O}_{2}$ uptake in biofilms during phenol exposure was less than expected when compared to inhibition of DFR biofilm activity under similar phenol concentrations. A notable difference between the microsensor profiles (Fig. 4) and biofilm inhibition tests performed in the DFR (Fig. 5) is the fluid environment around the biofilms in the DFR and the microsensor measuring chamber. There was a significant bulk liquid phase in the microsensor measuring chamber compared to a thin film layer in the DFR, which resulted in lower $\mathrm{O}_{2}$ transfer than achieved from the headspace in the DFR. The difference in $\mathrm{O}_{2}$ uptake is evidenced by the $\mathrm{NO}_{2}^{-}$production in the $\mathrm{DFR}$, where $2.75 \mathrm{mM} \mathrm{NO}_{2}^{-}$was present in the reactor effluent. The AOB stoichiometry of 1.5 $\mathrm{O}_{2}: \mathrm{NO}_{2}^{-}$predicts that the $\mathrm{O}_{2}$ consumed in the DFR would be $4.1 \mathrm{mmol} \mathrm{O}_{2} \mathrm{~L}^{-1}$, which is much higher than the diffusion-limited transfer of DO through the bulk liquid of the microsensor chamber, which has an upper limit of $0.257 \mathrm{mmol} \mathrm{O}_{2} \mathrm{~L}^{-1}$, the atmospheric solubility of DO at $25^{\circ} \mathrm{C}$.

In the DFR, an overall $\mathrm{NO}_{2}^{-}$production rate was determined based on bulk fluid concentrations of influent and effluent $\mathrm{NO}_{2}^{-}$ and overall protein measurements (Table 2). A reactive transport biofilm model described elsewhere (Lauchnor, 2011) was used to simulate the DO microsensor profiles in the biofilm and predict $\mathrm{NO}_{2}^{-}$production rates (Table 2). The control (no phenol) DO profile was simulated to match the data and the resulting total $\mathrm{NO}_{2}^{-}$production rate was $6.5^{*} 10^{-8} \mathrm{~mol} \mathrm{~m}^{-1} \mathrm{~s}^{-1}$. Assuming 
$50 \%$ biofilm coverage of the slide, a protein normalized rate of $0.0015 \mathrm{mmol} \mathrm{NO}_{2}^{-} \mathrm{mg}$ protein ${ }^{-1} \mathrm{~h}^{-1}$ was estimated from the DO profile which was an order of magnitude lower than in the DFR and two orders of magnitude lower than batch cells (Table 2). The results of inhibition tests at higher concentrations of phenol in both suspended and biofilm cells shown in Table 2, agree with the same trend as the results at $20 \mu \mathrm{M}$ phenol exposure. This lower $\mathrm{NH}_{3}$ oxidizing activity in the biofilm is consistent with the lower degree of inhibition observed compared to the DFR.

\subsection{Biofilm resistance and slow growth rate}

In the biofilms, $\mathrm{O}_{2}$ availability controlled the rates of $\mathrm{NO}_{2}^{-}$ production. Conversely, in suspended cell reactors $\mathrm{O}_{2}$ limitation was not present and $\mathrm{NH}_{3}$ was the limiting substrate controlling rates of growth in the fill-and-draw and chemostat cultures, which was confirmed by stoichiometric mass balances of $\mathrm{NO}_{2}^{-}$production. Regardless of whether the limiting substrate was $\mathrm{O}_{2}$ or $\mathrm{NH}_{3}$, the same general trend was observed in both suspended and biofilm cultures, where the increased rates of $\mathrm{NO}_{2}^{-}$production caused greater inhibition during phenol exposure.

\section{Conclusions}

- One of the key factors that made the N. europaea biofilms more resistant to inhibition by phenol was the lower metabolic activity of the cells.

- The results suggest that increased AMO turnover rate dictates the sensitivity to phenol by increasing the potential interaction of phenol with the enzyme. This was observed in this study with an inhibitor that interacts directly with the AMO enzyme.

- These observations are significant for wastewater treatment operations where the metabolism of $\mathrm{NH}_{3}$ oxidizing bacteria during biological treatment may affect their sensitivity to inhibition in both biofilm and suspended cell reactors. It would be of interest to determine if similar correlations between activity and inhibition exist with other inhibitors of $\mathrm{NH}_{3}$ oxidation in $\mathrm{N}$. europaea.

\section{Acknowledgments}

We thank Luis Sayavedra-Soto for the N. europaea culture, and for assistance from Mohammad Azizian with analytical techniques, Brian Wood with the modeling analysis, and Tyler Radniecki with the chemostat tests. We thank undergraduate researcher Nicole Bauer for assistance with fill-and-draw reactors. This research was funded by the National Science Foundation with an Integrated Graduate Education and Research Traineeship (IGERT) fellowship (EGL) and a grant from the NSF's Division of Bioengineering and Environmental Systems Genome-Enabled Environmental Science and Engineering Program.

\section{R E F E R E N C E S}

Amor, L., Eiroa, M., Kennes, C., Veiga, M.C., 2005. Phenol biodegradation and its effect on the nitrification process. Water Research 39 (13), 2915-2920.

Anderson, G., O'Toole, G., 2008. Innate and induced resistance mechanisms of bacterial biofilms. Bacterial Biofilms 322, 85-105.

Arp, D.J., Sayavedra-Soto, L.A., Hommes, N.G., 2002. Molecular biology and biochemistry of ammonia oxidation by Nitrosomonas europaea. Archives of Microbiology 178 (4), 250-255.

Borriello, G., Werner, E., Roe, F., Kim, A.M., Ehrlich, G.D., Stewart, P.S., 2004. Oxygen limitation contributes to antibiotic tolerance of Pseudomonas aeruginosa in biofilms. Antimicrobial Agents and Chemotherapy 48 (7), 2659-2664.

Chandran, K., Love, N.G., 2008. Physiological state, growth mode, and oxidative stress play a role in Cd(II)-mediated inhibition of Nitrosomonas europaea 19718. Applied and Environmental Microbiology 74 (8), 2447-2453.

Costerton, J.W., Stewart, P.S., Greenberg, E.P., 1999. Bacterial biofilms: a common cause of persistent infections. Science 284 (5418), 1318-1322.

Ely, R.L., Williamson, K.J., Hyman, M.R., Arp, D.J., 1997. Cometabolism of chlorinated solvents by nitrifying bacteria: kinetics, substrate interactions, toxicity effects, and bacterial response. Biotechnology and Bioengineering 54 (6), 520-534.

Gieseke, A., deBeer, D., 2004. Use of microelectrodes to measure in situ microbial activities in biofilms, sediments, and microbial mats. In: Kowalchuk, G.A., de Bruijn, F., Head, I., Akkermans, A., van Elsas, J. (Eds.), Molecular Microbial Ecology Manual, second ed. Springer, Heidelberg.

Hageman, R.H., Hucklesby, D.P., 1971. Nitrate reductase from higher plants. Methods in Enzymology 23, 491-503.

Hyman, M.R., Sansome-Smith, A.W., Shears, J.H., Wood, P.M., 1985. A kinetic-study of benzene oxidation to phenol by whole cells of Nitrosomonas europaea and evidence for the further oxidation of phenol to hydroquinone. Archives of Microbiology 143 (3), 302-306.

Keener, W.K., Arp, D.J., 1993. Kinetic-studies of ammonia monooxygenase inhibition in Nitrosomonas europaea by hydrocarbons and halogenated hydrocarbons in an optimized whole-cell assay. Applied and Environmental Microbiology 59 (8), 2501-2510.

Keener, W.K., Arp, D.J., 1994. Transformations of aromatic compounds by Nitrosomonas europaea. Applied and Environmental Microbiology 60 (6), 1914-1920.

Lauchnor, E.G., 2011. Inhibition, Gene Expression and Modeling of Ammonia Oxidation in Biofilms of Nitrosomonas Europaea. Oregon State University. Ph.D. dissertation.

Lauchnor, E.G., Radniecki, T.S., Semprini, L., 2011. Inhibition and gene expression of Nitrosomonas europaea biofilms exposed to phenol and toluene. Biotechnology and Bioengineering 108 (4), 750-757.

Li, J., Bishop, P.L., 2002. In situ identification of azo dye inhibition effects on nitrifying biofilms using microelectrodes. Water Science and Technology 46 (1-2), 207-214.

Mah, T.F.C., O’Toole, G.A., 2001. Mechanisms of biofilm resistance to antimicrobial agents. Trends in Microbiology 9 (1), 34-39.

Powell, S.J., Prosser, J.I., 1986. Inhibition of ammonium oxidation by nitrapyrin in soil and liquid culture. Applied and Environmental Microbiology 52 (4), 782-787.

Powell, S.J., Prosser, J.I., 1992. Inhibition of biofilm populations of Nitrosomonas europaea. Microbial Ecology 24 (1), 43-50.

Prosser, J.I., 1989. Autotrophic nitrification in bacteria. Advances in Microbial Physiology 30, 125-181. 
Radniecki, T.S., Dolan, M.E., Semprini, L., 2008. Physiological and transcriptional responses of Nitrosomonas europaea to toluene and benzene inhibition. Environmental Science \& Technology 42 (11), 4093-4098.

Radniecki, T.S., Semprini, L., Dolan, M.E., 2009. Expression of merA, amoA and hao in continuously cultured Nitrosomonas europaea cells exposed to zinc chloride additions.

Biotechnology and Bioengineering 102 (2), 546-553.

Rasche, M.E., Hicks, R.E., Hyman, M.R., Arp, D.J., 1990. Oxidation of monohalogenated ethanes and $n$-chlorinated alkanes by whole cells of Nitrosomonas europaea. Journal of Bacteriology 172 (9), 5368-5373.
Satoh, H., Sasaki, Y., Nakamura, Y., Okabe, S., Suzuki, T., 2005. Use of microelectrodes to investigate the effects of 2-chlorophenol on microbial activities in biofilms. Biotechnology and Bioengineering 91 (2), 133-138.

Spoering, A.L., Lewis, K., 2001. Biofilms and planktonic cells of Pseudomonas aeruginosa have similar resistance to killing by antimicrobials. Journal of Bacteriology 183 (23), 6746-6751.

Wood, P.M., 1986. Nitrification as a bacterial energy source. In: Prosser, J.I. (Ed.), Nitrification. Society for General Microbiology (IRL Press), Washington, D. C., pp. 39-62. 